ENTREPRENEURSHIP AND SUSTAINABILITY ISSUES

ISSN 2345-0282 (online) http://jssidoi.org/jesi/

2020 Volume 8 Number 2 (December)

http://doi.org/10.9770/jesi.2020.8.2(26)
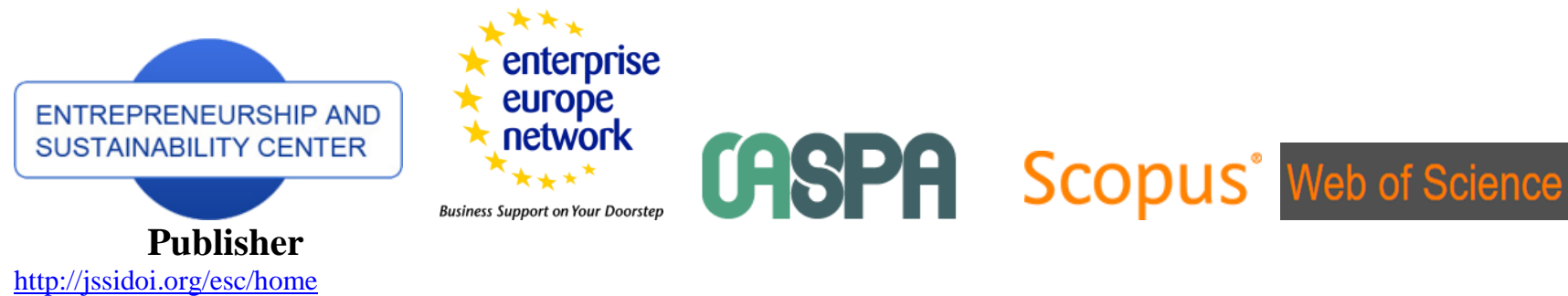

http://jssidoi.org/esc/home

Business Support on Your Doorstep

1) Clarivate

Analytics

\title{
ORGANISATIONAL SECURITY CULTURE IN SMALL ENTERPRISES: A CASE STUDY
}

\author{
Janusz Gierszewski ${ }^{1}$, Andrzej Pieczywok ${ }^{2}$ \\ ${ }^{1}$ Pomeranian University in Stupsk, Krzysztofa Arciszewskiego 22A, 76-200 Stupsk, Poland \\ ${ }^{2}$ Kazimierz Wielki University in Bydgoszcz, Jana Karola Chodkiewicza 30, 85-064 Bydgoszcz, Poland \\ E-mail: ${ }^{*}$ janusz.gierszewski@apsl.edu.pl (Corresponding author); ${ }^{2}$ a.pieczywok@wp.pl
}

Received 15 March 2020; accepted 25 August 2020; published 30 December 2020

\begin{abstract}
The cultural crisis and the sense of loss of contemporary man are in a way a consequence of the imbalance between the uneven development of the sphere concerning his mentality and the technical and technological progress in the workplace. An increasingly important element of the contemporary human working environment is the culture of security, and one of its important parts is the organisational culture. This culture manifests itself in the behaviours and relations of individuals and employee teams, in courts and attitudes, in the way of solving problems and conflicts, organising work and human cooperation. It is an inseparable element of interpersonal relations and shaping order between cooperating people. The subject of the research was the organisational culture of TECHZBYT trade company. However, the aim is to determine to what extent the organisational culture of TECHZBYT company influences the level of employee security culture. Based on the subject and aim of the research, the following main research problem was formulated: What is the impact and significance of TECHZBYT's organisational culture on the effectiveness of operation and on the level of employee security culture? The research area has been made the TECHZBYT company, which is a local trading company with a certified quality management system in accordance with the requirements of the ISO 9002 standard. It is a leading trading and service company located in the Pomeranian Province, which deals with trade in metallurgical and construction products. The mission of TECHZBYT Sp. z o.o. is to meet customer expectations by distributing construction products of excellent quality in convenient places. The surveyed group consisted of employees of Techzbytsp. z o.o. and the research method used was a diagnostic survey (questionnaire tool). The group consisted of 30 basic level employees. The article consists of several parts, in the first part there is an introduction to the issue. Next, selected examples of defining security culture are presented. In the next part, the author's team indicated the need to conduct research in the area of a given organisation. The final part is empirical research on the evaluation of security culture in the organisational behaviour of employees.
\end{abstract}

Keywords: organisational culture; security; organisation; security culture

Reference to this paper should be made as follows: Gierszewski, J., Pieczywok, A. 2020. Organisational security culture in small enterprises: a case study. Entrepreneurship and Sustainability Issues, 8(2), 438-453. http://doi.org/10.9770/jesi.2020.8.2(26)

JEL Classifications: L23 


\section{ENTREPRENEURSHIP AND SUSTAINABILITY ISSUES}

ISSN 2345-0282 (online) http://jssidoi.org/jesi/

2020 Volume 8 Number 2 (December)

http://doi.org/10.9770/jesi.2020.8.2(26)

Make your research more visible, join the Twitter account of ENTREPRENEURSHIP AND SUSTAINABILITY ISSUES: @Entrepr69728810

\section{Introduction}

The cultural crisis and the sense of loss of contemporary man are, in a way, a consequence of the imbalance between the uneven development of the sphere concerning his mentality and the technical and technological progress around it. Culture is an increasingly important element of the contemporary human security environment.

Therefore, the culture, and especially the culture of security, will be positively shaped by the broadly understood self-defence skills, supporting the strengthening of the sense of human security. We deal with it in all social strata and age ranges. Its knowledge, but above all the way it is manifested, influences the way we perceive and think about security. An important element of the culture of security is the subject's behaviours and actions, including his or her citizen's cooperation. All these elements become significantly more important in difficult or crisis situations, during which the culture of security is particularly visible.

A security culture is characteristic of all human activities in an organisation, including management, and affects all significant aspects of its functioning and the basic instruments and structure, strategy and procedure. Each organisation has its own specific characteristics, which influence what happens inside it and its contacts with the environment, often stronger than the authority of the leaders or the formal structure.

A culture of security is manifested in the behaviour and relations of individuals and employee teams, in courts and attitudes, in the way problems and conflicts are solved, work organisation and human interaction. It is an inseparable element of interpersonal relations and shaping order between cooperating people. The security culture in an organisation permeates all areas of activity of each institution, constituting a bridge between its past and future. Culture integrates, unifies, stabilizes, reduces uncertainty, promotes common vision of goals and facilitates finding ways to solve problems. It provides a strong foundation for the strategic activities of an organisation ( $\mathrm{J}$. Penc, 2010).

Security culture has quite a big connection with the broadly understood organisation culture. The starting point, and at the same time the main reason for its research was the need for information from management. The necessary information will enable or facilitate making a specific decision or a combination of decisions concerning the organisational improvement of the company, but also raise the security culture among employees to a higher level. Therefore, it is worthwhile to first of all examine the shape and profile of the organisational culture, identify the factors determining its change, determine its impact on the company's effectiveness, and assess the level of security culture.

The subject of the research was the organisational culture of TECHZBYT trade company. However, the aim is to determine to what extent the organisational culture of TECHZBYT company influences its task effectiveness on the one hand and on the other hand the level of employee security. On the basis of the subject and aim of the research, the following main research problem was formulated: What is the impact of TECHZBYT's organisational culture on the effectiveness of its functioning and on the level of employee security culture?

The following specific problems were formulated:

1) How is organisational culture understood and perceived by the subjects and what are its main determinants?

2) Which elements of the company's activities are most influenced by the organisational culture? 


\section{ENTREPRENEURSHIP AND SUSTAINABILITY ISSUES}

ISSN 2345-0282 (online) http://jssidoi.org/jesi/

2020 Volume 8 Number 2 (December)

http://doi.org/10.9770/jesi.2020.8.2(26)

Make your research more visible, join the Twitter account of ENTREPRENEURSHIP AND SUSTAINABILITY ISSUES: @Entrepr69728810

3) What is the relationship between the company's organisational culture and the security culture of employees?

The research area has been made the TECHZBYT company, which is a local trading company with a quality management system certificate in accordance with the requirements of the ISO 9002 standard. It is a leading trade and service company located in the Pomeranian Province, which deals with trade in metallurgical and construction products. The mission of TECHZBYT Sp. $\mathrm{z}$ o.o. is to meet customer expectations by distributing construction products of excellent quality to for their customers' convenient places.

The group studied consisted of employees of Techzbyt sp. z o.o. The research method used was a diagnostic survey and a survey questionnaire. The surveyed persons were divided into two groups. The first group consisted of the managerial staff in the number of 10 people, the second group consisted of the basic level employees in the number of 30 people.

\section{Selected examples of defining a security culture}

Culture is characteristic of all human activities within an organisation, including management, and affects all significant aspects of its functioning, including its basic instruments and structure, strategy and procedure. Each organisation has its own specific property, which influences what happens inside it and its contacts with the environment, often stronger than the authority of leaders or formal structure. Culture manifests itself in the behaviour and relations of individuals and employee teams, in courts and attitudes, in the way problems and conflicts are solved, in the organisation of work and human interaction. It is an inseparable element of interpersonal relations and shaping order between cooperating people. Culture permeates all areas of activity of each institution, being a bridge between its past and future. Culture integrates, unifies, stabilizes, reduces uncertainty, promotes a common vision of goals and facilitates finding ways to solve problems. It provides a strong foundation for the strategic activities of an organisation (Penc, 2010).

A review of various cultural concepts by A.L. Kroeber and C. Kluckhohn gave rise to a comprehensive, multifaceted definition by them: "Culture consists of overt and covert patterns, of behaviours learned and transmitted by symbols, forming the specific heritage of human groups, and of the products of these behaviours: the core of culture are traditional, i.e. grown and selected in a historical process, ideas, and the values attached to them; cultural systems can be considered either as products of human activity or as conditions for further human activity" (Kroeber, \& Kluckhohn, 1952).

This definition, very broadly speaking, is a kind of a boundary - on the one hand closing the historical aspect of the term's development, and on the other hand it contains a very rich collection of contemporary humanities, in the circle of research of which there is also culture, often giving the basis for formulating contemporary definitions of the term.

It is also worth mentioning here the rather commonly used form of classification of cultural fields, dividing it into material and spiritual. Very often the boundary between material and spiritual culture coincides with the distinction between culture and civilisation. The distinction between material and spiritual culture is often speculative. Nevertheless, these divisions seem important (culture - civilisation, spiritual culture - material culture), as the whole will constitute culture in a broad sense. 


\section{ENTREPRENEURSHIP AND SUSTAINABILITY ISSUES}

ISSN 2345-0282 (online) http://jssidoi.org/jesi/

2020 Volume 8 Number 2 (December)

http://doi.org/10.9770/jesi.2020.8.2(26)

Make your research more visible, join the Twitter account of ENTREPRENEURSHIP AND SUSTAINABILITY ISSUES: @Entrepr69728810

The culture of security through its elements allows to create a certain key to the interpretation of events, to direct actions aimed at strengthening the sense of human security. The use of its potential enables the creation of a stable environment conducive to security in its broadest sense.

The term security culture was first used by the Atomic Energy Agency, which issued a report on the Chernobyl disaster. Security culture is treated as a component of the organisational and social culture and as a whole of collective actions consisting of the application of organisational and interorganisational practices aimed at the protection of the individual employee and the entire working environment (Gherardi, Niccolini, 2000). The culture is also a set of values and beliefs within the organisation, creating specific patterns of behaviour. It is the result of individual and collective values, characteristics, perceptions, competences and patterns of behaviour that determine commitment to health and security at work.

The very concept of security culture, according to Professor M. Cieślarczyk is "a model of basic assumptions, values, norms, rules, symbols and beliefs characteristic for a given subject, influencing the way it perceives challenges, opportunities and/or threats in its closer and further environment, as well as the way it feels and thinks about security (...), and the related way of behaviour and action (cooperation), in various ways "learned" and articulated by this subject, in the processes of education in its broadest sense, including natural processes of internal integration and external adaptation and other organisational processes (...), as well as in the process of strengthening the defence in its broadest sense (not only militarily) (...), serving the harmonious development of this entity and its achievement of security in its broadest sense, for the benefit of itself and its environment" (Cieślarczyk, 2009).

And A. Filipek writes: "the culture of security can be treated as specific tendencies of individual communities or social groups, conditioned by an accepted hierarchy of values, serving to build a broadly understood defence, the result of which will be the actual ability to prevent threats, as well as the ability to create one's own development, conducive to the preservation and renewal of identity" (Filipek, 2008). Despite some differences in the interpretation of the term "security culture", it can be seen that both definitions attach great importance to the issue of values. This means that shaping the broadly understood security of students, based on an internal hierarchy of values, will be a manifestation of an important aspect of their security culture.

One of the most popular definitions of occupational security culture developed by the UK Health and Safety Executive (HSE) indicates that an occupational security culture is the result of individual and group values, attitudes, perceptions of competence, behavioural patterns and the style and quality of security management in an organisation. Organisations with a positive security culture are characterised by communication based on mutual trust, a common perception of the importance of security and confidence in the effectiveness of preventive measures (Horbury, Bottomley, 1997).

Shaping an appropriate security culture is one of the important elements of occupational health and safety/security management (Polish Standard PN-N-18001, 1999). Shaping a security culture is a continuous and multidimensional process to which all groups of employees in the company must submit. It is as much about passing on the relevant theoretical knowledge as it is about introducing it into everyday use. A safe work culture is created and then reproduced according to the system of accepted meanings in a given group of employees. Employees will only be willing to repeat their behaviour according to the adopted pattern if the adopted pattern is an understandable, obvious and unquestionable way of behaviour for them. 


\section{ENTREPRENEURSHIP AND SUSTAINABILITY ISSUES}

ISSN 2345-0282 (online) http://jssidoi.org/jesi/

2020 Volume 8 Number 2 (December)

http://doi.org/10.9770/jesi.2020.8.2(26)

Make your research more visible, join the Twitter account of ENTREPRENEURSHIP AND SUSTAINABILITY ISSUES: @Entrepr69728810

M. Cieślarczyk calls the dimensions of security culture "pillars of security culture" (Cieślarczyk, 2010). The components of these dimensions intertwine to some extent. For example, knowledge, which is a component of the first dimension of the culture of security, in addition to the values and principles that are recognised by man, is also the domain of the second rational-organisational-legal dimension of the culture of security (also connected with technical thought).

While recognizing the types, characteristics and dimensions of a security culture, one should not forget about its very close relationship to security

For both security and culture, there are two simultaneous characteristics - space and time. Physical space gives room for the emergence of security regions or threat areas and allows culture to expand to cover more and more territory.

Time creates a system of reference in which the process of building a culture takes place in a certain territory, twinned with the process of development of human individuals, social groups and entire nations - this development determines the level of their security.

The development process is the most powerful prevention mechanism, counteracting all threats and, even according to the definition of security - can be considered as an analogy of a security phenomenon in the process.

Culture is not only a certain "added value", but also represents an autonomous potential for the defence of the actors - in the military, political, socio-cultural, economic, environmental, health, and in such spheres of activity as legal-organisational, technogenic or cybernetic.

Culture in relation to entities operating in the area of its impact, from the personal scale to the social scale, is a mechanism that can influence the attitudes and behaviour of these entities in specific situations, processes or events that bring with them various challenges, opportunities, risks and threats (Piwowarski, 2016).

In our view, the culture of security is the awareness of shaping life in the perspective of the broadly understood balance between the structural thesis and deconstructive antithesis, is a subjective sense and, at the same time, a holistic way of thinking, a form of subjective activity in shaping the most perfect forms of existence, inscribed in sustainable development directions. In terms of safety culture, it is worth emphasizing the role of the subject's autonomy as a conscious person, perceiving and assessing processes and phenomena occurring in the environment and adequate to the needs of its change (Gierszewski et al. 2020).

Subjectivity embedded in the space of security is a reflection of the ontological, epistemological and ethical paradigm, and the culture of security is the pursuit of the development and improvement of such forms of duration that best meet the needs and ideas of the subject. The very expression "security culture" implies a humanistic provenance of security and stains its subjective dimension. Therefore, it is worth asking a question about the place and role of shaping a safety culture in an organisation.

The term 'security culture' refers to society, a group of people or organisations, and to individuals. That is why the culture of public, enterprise and individual security can be distinguished. The security culture of an enterprise is an important for employees' state of awareness of threats, standards of conduct in an emergency and organisational processes that affect the taking into account of safety in the company, organising tasks, supervising and assessing employees and explaining the causes of accidents. Security culture can also serve as a very useful theoretical model, having an explosive power, useful among others in the discipline of security sciences. Security 


\section{ENTREPRENEURSHIP AND SUSTAINABILITY ISSUES}

ISSN 2345-0282 (online) http://jssidoi.org/jesi/

2020 Volume 8 Number 2 (December)

http://doi.org/10.9770/jesi.2020.8.2(26)

Make your research more visible, join the Twitter account of ENTREPRENEURSHIP AND SUSTAINABILITY ISSUES: @Entrepr69728810

culture is quite an important determinant of the broadly understood organisation culture. The origins of the concept of "organisation culture" can be seen in the development of two currents in organisation and management theory. The first stream originates from the company's environment and stems from questions about the influence of the national culture of a particular community on management. The second is the so-called behavioural school, where interpersonal processes and group dynamics within an organisation are of interest (C. Douglas, 2017). In economic literature, depending on the concept and approach, the definitions of organisational culture take very different shapes. Some researchers represent the view that culture is not something that an organisation has, culture is something that an organisation is, while others claim that culture exists within an organisation.

The distinction between "good" security culture and "bad" culture suggests that there are some specific properties correlating with the safe operation of the enterprise.

The elements of company culture are: tradition, norms (directives, principles), system of values (ideas and images) and beliefs (human attitudes and their orientations, e.g. for market activities), as well as various creations of a given culture called artefacts, which are visible and aware on the outside (physical artefacts - material creations of a given culture, such as: art, technology, material objects; behavioural artefacts, such as ceremonies and rituals, and linguistic artefacts, such as the specific language of an organisation, myths and legends).

\section{The need for research into the security culture in the organisation}

A security culture plays quite an important role in any environment that creates social capital. The organisation's environment is also an important reference. In this environment it needs to be based on positive values indicating clear rules of conduct. Employees should have a conviction of the quality and universality of their work. Organisations are the place where the employee does his or her job, on the one hand, and should work on his or her personal and professional (specialist) development on the other. A positive attitude towards oneself translates into a friendly and favourable attitude towards others. This makes it possible to learn about one's own potential perceived as a source of life energy, self satisfaction and achievements. Internal calmness together with acquired knowledge and skills leads to innovation and creativity in creative solving of widely understood problems. These are benefits that result from the full use of the potential inherent in the culture of security. It should also be stressed that the use of a cultural perspective in an organisation's environment can foster a better understanding of many dimensions of human security among employees. Using the potential of a security culture to build broadly understood employee coherence allows reducing the specific gap between growth and the ability to meet security needs. This will enable employees to counteract failures and use opportunities and challenges to their advantage.

Recently, there has been an increase in the number of accidents in organisations related to employees' noncompliance with security culture. It seems that organisations are a special place to promote and develop knowledge, technology and security culture. Therefore, it is important to assess the key aspects of security culture related to occupational risk assessment, prepare employees for emergencies, the health and security training process, preventive health protection and attitude to threats. Health and security training and evacuation exercises in many organizations are rare. Organizations care for the safety of their employees differently, while educating them little in the field of health and security and fire protection, first aid and crisis management.

The risks posed by employees in the organisation may come from three sources. First, incorrect behaviour of the employee himself. Disregard for the threat and instructions, insufficient focus on the activity, unexpected surprise, haste. Sometimes, it is inappropriate for an employee to behave arbitrarily, including: performing activities without removing hazards in the danger zone, entering or entering the danger zone without making sure that there 
ENTREPRENEURSHIP AND SUSTAINABILITY ISSUES

ISSN 2345-0282 (online) http://jssidoi.org/jesi/

2020 Volume 8 Number 2 (December)

http://doi.org/10.9770/jesi.2020.8.2(26)

Make your research more visible, join the Twitter account of ENTREPRENEURSHIP AND SUSTAINABILITY ISSUES: @Entrepr69728810

is no danger, not using personal and collective protection equipment and safety devices. The impact of negative psychophysical factors may deteriorate an employee's state of health, reduce their intellectual performance or even cause illness. Thirdly, from the so-called social work environment (bad interpersonal relations prevailing in the organisation). Violence, aggression, emotional blackmail, verbal insults, racism, bullying, sexual harassment can lead to physical and mental illness. Depression, concentration disorders, anxiety, neurosis, suicidal thoughts these are just some of the ailments accompanying the bullying of employees. Long-term tension can also result in heart, circulatory, stomach or intestinal diseases, shortness of breath, headaches and often permanent insomnia (Bernardi, 2019).

It should be stressed that the need to research the security culture in an organisation is also influenced by the improvement of working conditions, especially in practical (specialist) work. Thus, achieving optimal working conditions and reducing the risk to an acceptable level will improve security. However, ensuring adequate working conditions is not enough, as much depends on the employees themselves, both mentally and practically. If technical and system solutions for security are already in place in organisations, we can only achieve an improvement in security culture. Creating a high security culture among employees requires the organisation to be seen to be committed to security and life and health protection. Special attention to the development of a security culture deserves training to create the right attitudes and raise awareness among employees as part of a health and security culture. A high security culture significantly reduces the number of accidents at work, and training in this area makes it possible to raise the awareness of university staff in the field of occupational health and security and reduce accidents.

There are three main factors that contribute to the emergence of organisational security cultures: management commitment, responsibility and awareness (Bulgurcu et al. 2010; Herath and Rao 2009). Management commitment can be measured by perceiving management's efforts to achieve organisational goals, which is reflected in an organisational culture based on employee engagement and adapting goals to effectiveness (Knapp et al. 2006).

Views on the culture of the organisation were built over many years and were influenced by case studies that the authors implemented in various aspects of security, including security management and culture (Shedden et al., 2006; Maynard, Ruighaver, 2006, Koh et al.). In some case studies, the safety security culture was observed as part of understanding other aspects of safety security, while in others particular emphasis was placed on the safety security culture of the organization. Our research concerned an organisation where decision making in terms of security was dispersed and loosely controlled.

\section{Security culture in the organisational behaviour of employees}

Men prevailed among the surveyed employees, who constituted over $83 \%$ of the respondents ( 25 people). The structure of employees is similarly distributed by gender (see figure 1). 
Make your research more visible, join the Twitter account of ENTREPRENEURSHIP AND SUSTAINABILITY ISSUES: @Entrepr69728810

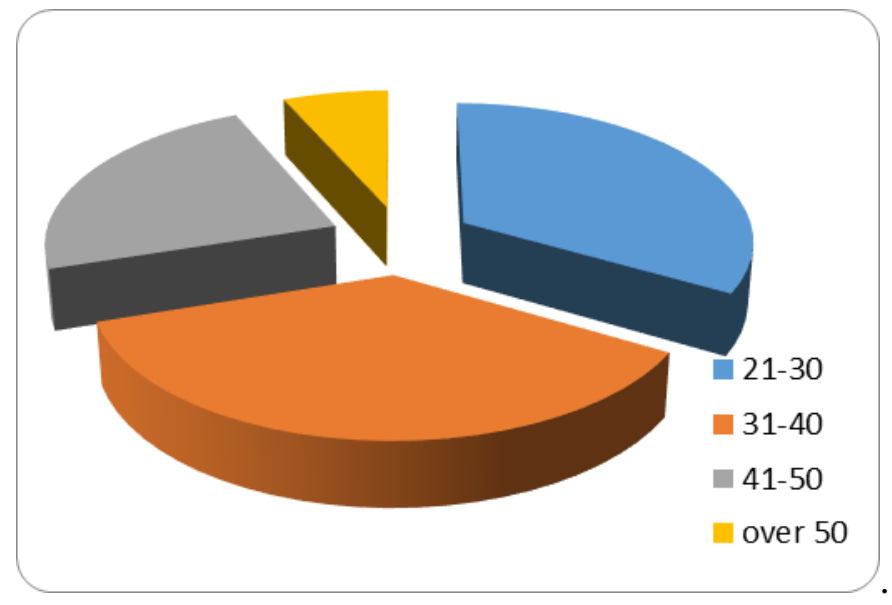

Fig. 1. Age structure of respondents

The dominant group of employees in terms of age are middle-aged people, i.e. 31-40 years of age - about 37\%, the second group are young people up to 30 years of age - about 33\%. In terms of education, the dominant group of respondents were people with secondary education. Among 30 respondents - 24 were with secondary education i.e. $80 \%$, five with higher education (17\%). Among the surveyed employees there is one person with vocational education. Among the employees, $20 \%$ had seniority of up to five years, of which $13 \%$ had up to five years and $7 \%$ had up to one year. The most numerous group were people working from 6 to 10 years, - about $47 \%$. A large group was made up of people who had worked in the company for 11 years or more - 10 people among the respondents - i.e. $33 \%$ (see figure 2).

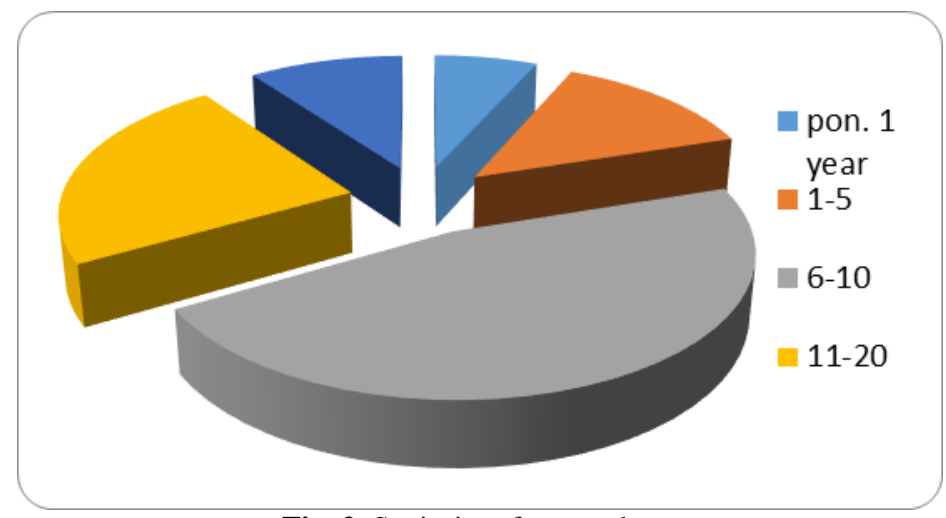

Fig. 2. Seniority of respondents

Among the respondents there were 10 people who held managerial or managerial positions in retail outlets. The remaining 20 people were sales department employees and employees employed in the company's headquarters.

The next question asked to the employees was the question related to satisfaction with their work. $73 \%$ of people answered that they were satisfied or rather satisfied. With only $23 \%$ fully satisfied, the remaining $50 \%$ were rather satisfied. About $17 \%$ were dissatisfied with their work. Those who did not have an opinion or did not care - $10 \%$. The figure 3 below shows these relationships. 
Make your research more visible, join the Twitter account of ENTREPRENEURSHIP AND SUSTAINABILITY ISSUES: @Entrepr69728810

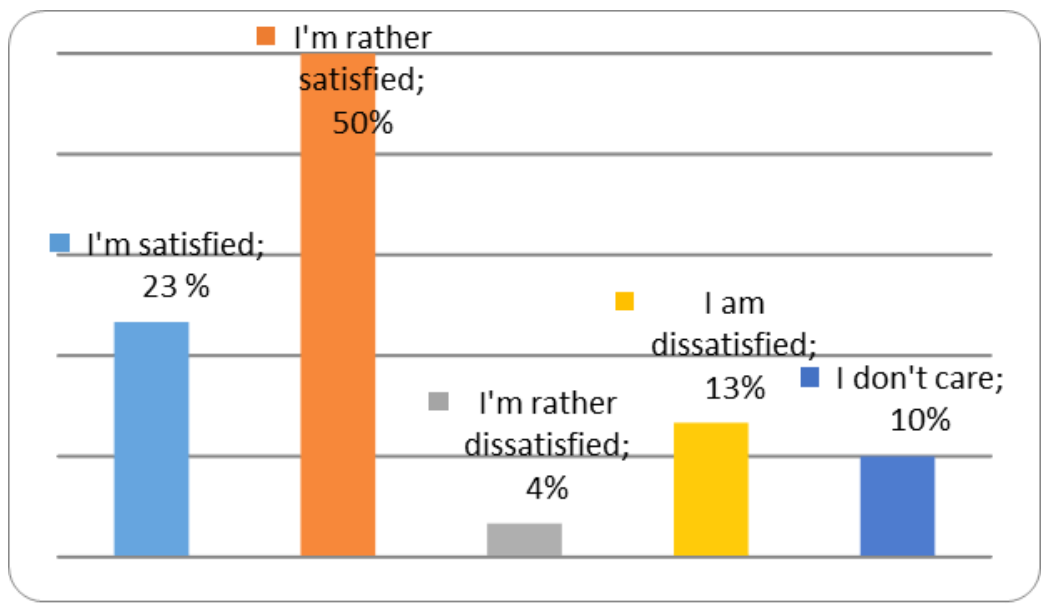

Fig. 3. Satisfaction with the work performed

The next question was about how to understand the definition of organisational culture. The figure 4 below shows the distribution of answers.

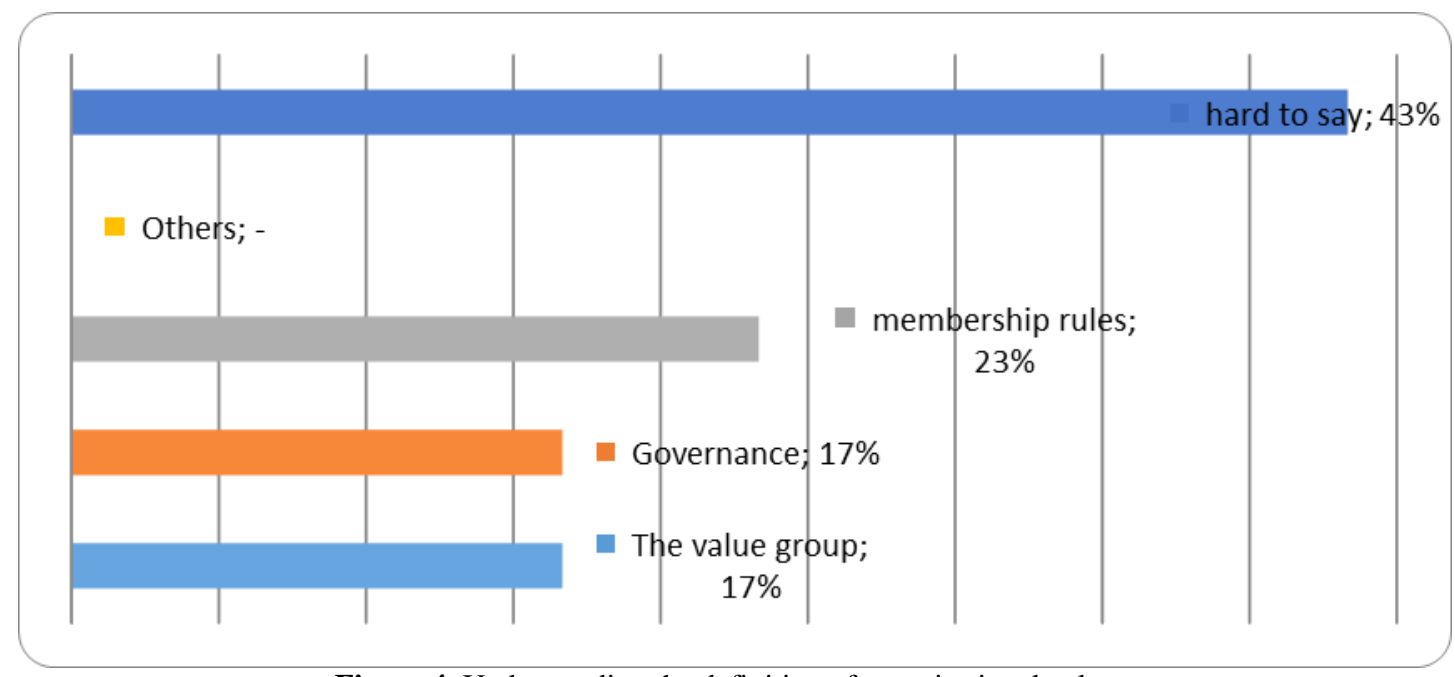

Figure 4. Understanding the definition of organisational culture

A very large percentage of respondents did not know what it was and how it defined the concept of organisational culture. Over $43 \%$ of the respondents were unable to answer what organisational culture is. $23 \%$ answered - that it is a set of values of tradition, beliefs, attitudes that function within the company. $17 \%$ each considered that there are rules of belonging to a given company and that there is a way of management, organisational climate and interpersonal relations.

As almost half of the people did not know what organisational culture was in the next question about the detailed character of organisational culture, whether it is positive or negative, conservative or innovative, masculine/female or silane/weak respondents had a problem with answering this question. Most - 20 people answered that they did not know the answer to this question. Only 10 people - all managers were able to answer 
Make your research more visible, join the Twitter account of ENTREPRENEURSHIP AND SUSTAINABILITY ISSUES: @Entrepr69728810

the question. The scope of managers' answers about the nature of organisational culture is presented in the table 1 below.

Table 1. Nature of organisational culture according to the respondents

\begin{tabular}{|c|l|c|}
\hline \multirow{2}{*}{$\mathrm{N}}$. & \multicolumn{1}{|c|}{ Type of culture } & Number of indications \\
\hline 1 & conservative & 10 \\
\hline 2 & bureaucratic & 9 \\
\hline 3 & male & 8 \\
\hline 4 & strong & 8 \\
\hline 5 & female & 2 \\
\hline 6 & pragmatic & 1 \\
\hline
\end{tabular}

Most managers describe the organisational culture in Techzbyt sp. z o.o. as conservative, male, bureaucratic and strong. The next question concerned the influence of organisational culture on the functioning of Techzbyt sp. $\mathrm{z}$ o.o. Data on this subject is presented in the figure 5 below.

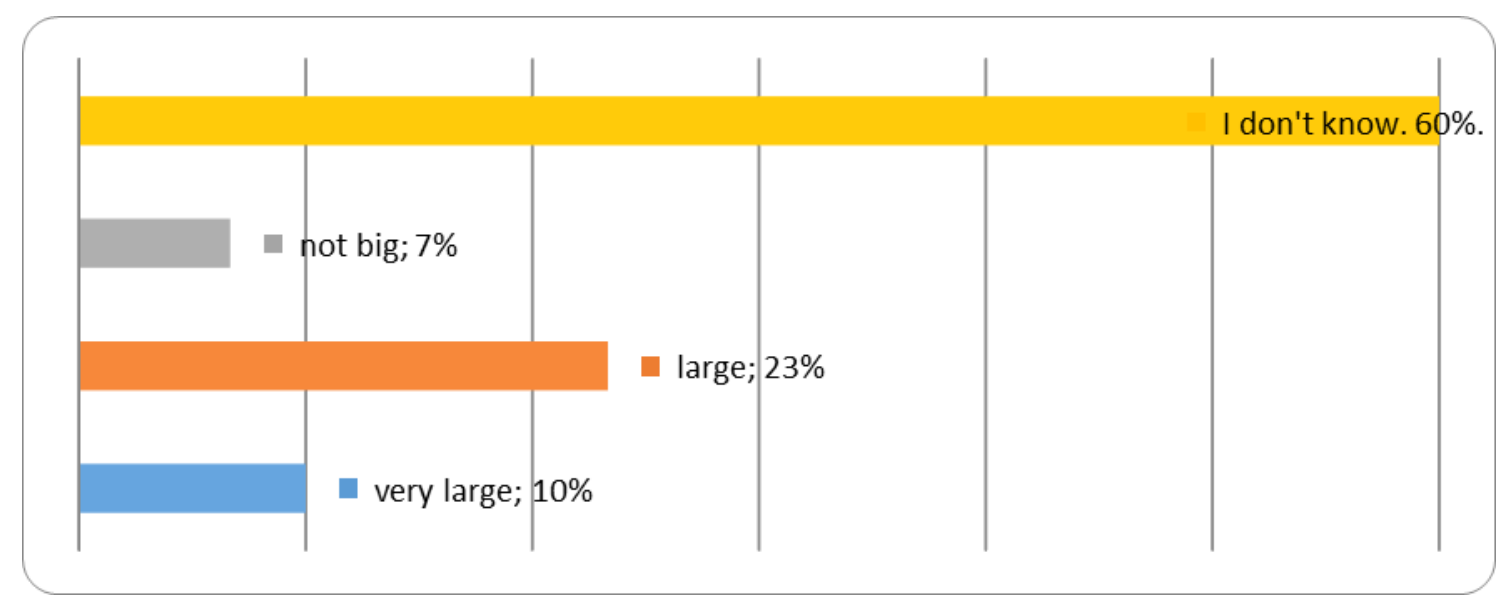

Figure 5. Understanding the definition of organisational culture

$60 \%$ of those surveyed did not know if such an impact existed on their company. $33 \%$ of those surveyed said it was large and very large. The answers were mainly given by managers, the rest replied that it was not large $-7 \%$ and they were most likely administrative staff.

In response to the question concerning the values of Techzbyt sp. z o.o. most of the respondents (50\%) replied that the company is profit-oriented. And $1 / 3$ of the respondents replied that they respect and care for the employee. A large percentage of those surveyed were not able to answer with what their company is aiming at. This information is illustrated by the figure 6 below. 
Make your research more visible, join the Twitter account of ENTREPRENEURSHIP AND SUSTAINABILITY ISSUES: @Entrepr69728810

Fig. 6. Evaluation of the values that Techzbyt is guided by

The respondents in the next question defined the factors that influence the development of the company. The answers were quite diverse. Only one factor received more than $30 \%$ of the indications. It concerned customer loyalty. The employees are aware that without customers the company will not function and thus will not develop (see table 2).

Table 1. Factors that influence the development of the company

\begin{tabular}{|c|l|c|c|}
\hline N. & Answers & number of people & $\%$ \\
\hline 1 & Leadership & 3 & 10 \\
\hline 2 & brand value & 3 & 10 \\
\hline 3 & Reputation & 1 & 3 \\
\hline 4 & knowledge of employees & 5 & 16 \\
\hline 5 & Culture & 1 & 3 \\
\hline 6 & Innovation & 2 & 6 \\
\hline 7 & Communication & 5 & 16 \\
\hline 8 & Customer loyalty & 10 & 33 \\
\hline 9 & Total & 30 & 100 \\
\hline
\end{tabular}

A high response rate of $17 \%$ was achieved by communication and staff knowledge. Three answers were given for leadership and brand value. The answer in the sales company concerning innovation is surprising. One answer each was given to the reputation, which is derived from the question of brand value and culture - as a factor influencing the development of the company.

The next question was whether the loyalty and commitment of employees is influenced by the culture of the organisation. As most of the respondents did not know the definition of culture, negative answers were obtained. Most of the respondents replied rather not (43\%). Only managers gave affirmative answers (34\% in total), but not definitely affirmative answers $(27 \%)$.

A positive aspect among the respondents is the knowledge of company strategy. The most. i.e. more than $90 \%$ of people know the company's strategy well or very well. Only $7 \%$ did not know the strategy to the end - giving answers rather not. A similar distribution of votes concerned the pleasant atmosphere at work. $40 \%$ of the 
ENTREPRENEURSHIP AND SUSTAINABILITY ISSUES

ISSN 2345-0282 (online) http://jssidoi.org/jesi/

2020 Volume 8 Number 2 (December)

http://doi.org/10.9770/jesi.2020.8.2(26)

Make your research more visible, join the Twitter account of ENTREPRENEURSHIP AND SUSTAINABILITY ISSUES: @Entrepr69728810

respondents answered definitely yes to this question. Another 53\% rather yes. Only 7\% of the respondents did not like the atmosphere at work - but answered rather not.

Since salespeople are obliged to wear special clothing with the company's logo in shops and company outlets, the question concerning the habit of wearing the logotype will be answered by $100 \%$ of those surveyed definitely yes $(83 \%)$ and rather yes $(17 \%)$. Those who answered yes are administrative employees who are not obliged to wear special clothing.

The next questions concerned the trainings organised by the company. The Management Board of Techzbyt sp. z o.o. has developed its own internal training program for its employees working in the sales department. Depending on the nature of work, they participate in various forms of training. The company organises cyclical, semi-annual conventions for its shop managers. During such conventions, the managers are acquainted with action plans for the coming months, but also participate in trainings organised by the Technical Service Department. For employees - salesmen, trainings on customer service are organised once a year. It takes place in 3-4 turns per year. Each such turn is attended by one employee from a given store, so that the staffing of a given facility is ensured. During such one-day training, employees receive knowledge of customer service, nice looks and tidy clothes. They also learn about new products offered in stores and their properties. During such training, they learn what to offer customers and how to advise them on product selection.

The evaluation of this system has been satisfactory. The training programme is evaluated well by the employees. Most of the answers were rather yes, which was $83 \%$, while $17 \%$ were very satisfied with the training system and what they achieved from it. The question of providing comments and ideas and opinions during the training is worse. Here, there are negative answers - rather not - but only - 17\%. Due to the fact that there is no motivation system in Techzbyt sp. z o.o., the questions concerning the existence of motivation and its role in the organisation were negative. Only two people think that there is an incentive system. The remaining 28 replied that they were unlikely to ( 25 people) or definitely not ( 3 people). Also negative answers were given to the question concerning the organisation of sport and recreation events, because the company does not organise them. Another issue in the questions was communication. The respondents were supposed to answer what, in their opinion, is the communication in the company. According to the respondents, communication at Techzbyt is insufficient (26 answers), inconsistent (17) and official (22 answers). It goes from top to bottom (27 answers) and is written. It is significant that negative answers were also given by managers, who most probably do not make any changes in this direction. The survey asked a question about what the employees are rated highest for. Most of the people surveyed answered, concerning professionalism at the workplace. There were as many as - 43\%, i.e. 13 people think so. Then it was focused on results - 7 people, i.e. 23\%, answered this way. Only in the third place the respondents indicated their knowledge - 20\% (i.e. 6 answers). Most probably, these were people working in administrative positions in accounting or technical department. The results are shown in the figure 7 below. 
Make your research more visible, join the Twitter account of ENTREPRENEURSHIP AND SUSTAINABILITY ISSUES: @Entrepr69728810

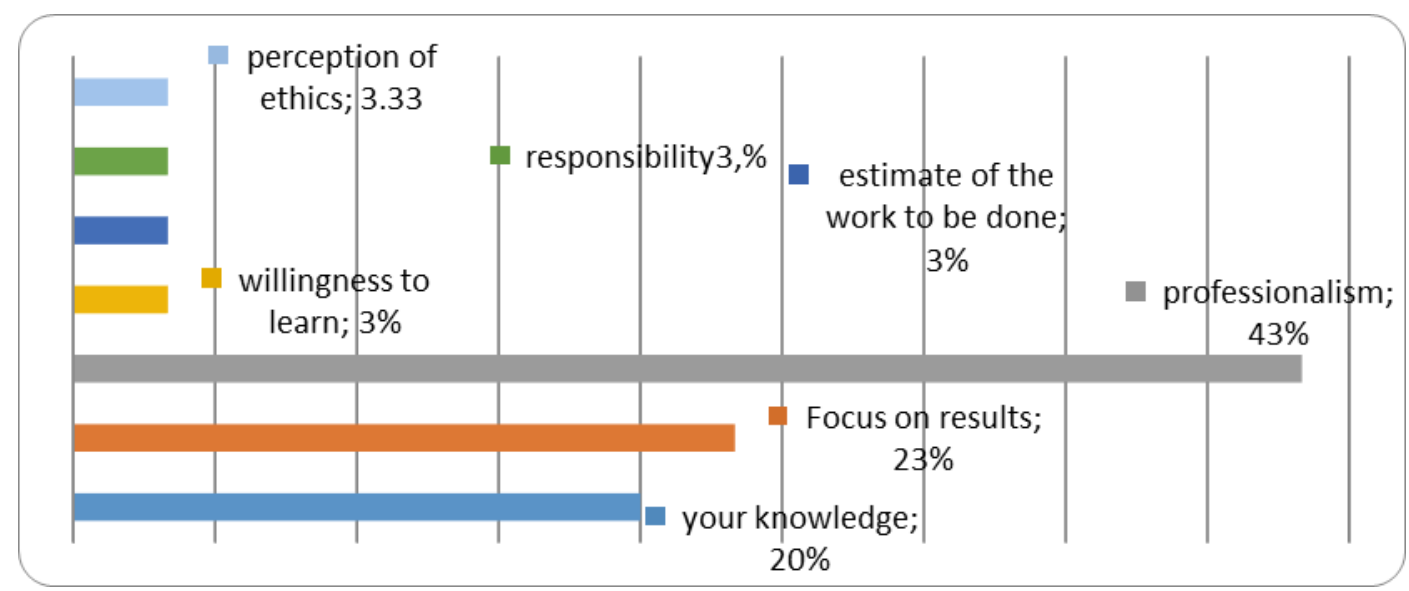

Fig. 7. Evaluation of the most evaluated areas of employees' functioning

The last question was what should be changed at Techzbyt. As far as changes in the way of management, control system and changing office equipment are concerned - the respondents did not answer (see figure 8).

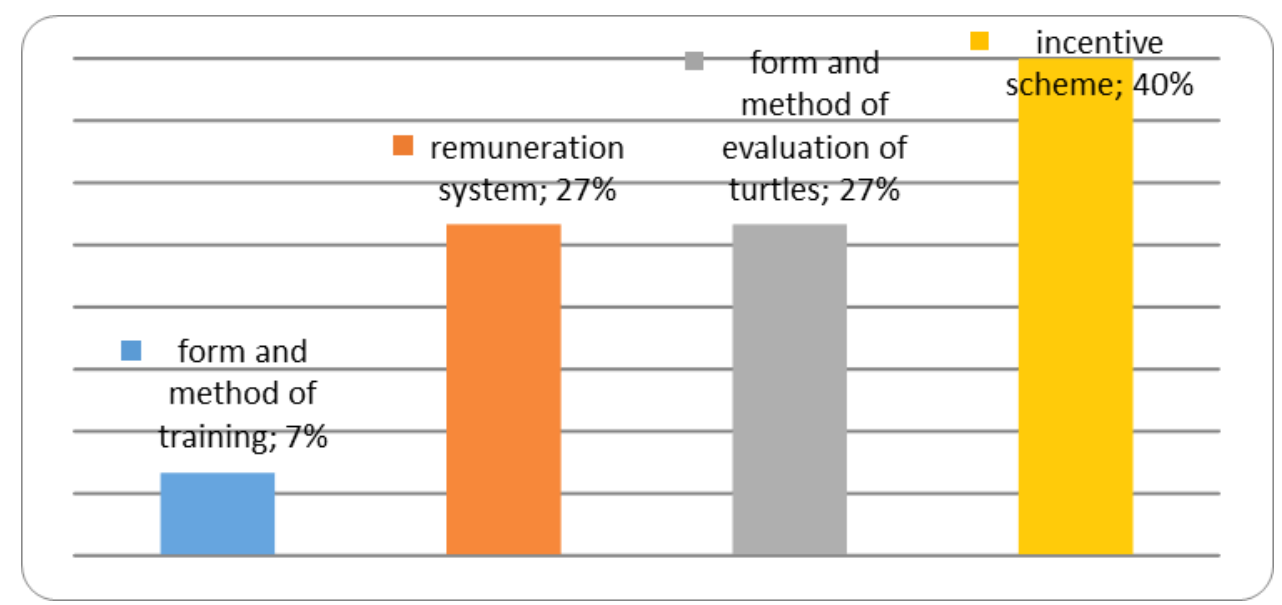

Fig. 8. Indication of changes in the modes of operation of the tested function and baad

On the other hand, the respondents want mainly changes in the motivation system - 40\% (12 people), the way of evaluating employees - 27\% ( 8 answers). The same number of respondents want changes in the remuneration system. Two people want changes in the way training is conducted.

\section{Conclusions}

The research conducted in Techzbyt Sp. z o.o. allowed to determine the functioning of the organisational culture in this company, which has quite a significant impact on the level of security culture. The lack of information about elements of culture in this company is clearly visible. To a large extent, the middle management of the company is to blame. Employees do not know what the organisational culture is, and how to relate its meaning to security and what it is characterized and manifests and what elements it contains. Employees do not know how to define the concept of organisational culture, only some of the employees in managerial positions know what it is. 


\section{ENTREPRENEURSHIP AND SUSTAINABILITY ISSUES}

ISSN 2345-0282 (online) http://jssidoi.org/jesi/

2020 Volume 8 Number 2 (December)

http://doi.org/10.9770/jesi.2020.8.2(26)

Make your research more visible, join the Twitter account of ENTREPRENEURSHIP AND SUSTAINABILITY ISSUES: @Entrepr69728810

After the survey, the following statements can be summarised:

1. Lack of information on the organisational culture among the ordinary employees of retail outlets (sellers), only partial knowledge of this issue among the ordinary administrative staff.

2. Managers are better aware of their organisational culture. However, they do not inform their subordinates.

3. There is a belief among the staff that the management of the company is solely profit-making. According to the respondents, there is a low level of respect and not enough care for employees.

4. There is a low level of satisfaction with the incentive system and the level of remuneration. The incentive system does not exist at the level of regular employees. The main beneficiaries of this system are managers of shops and retail outlets who receive discretionary bonuses.

5. The company's existing training system is satisfactory, but can be improved by making changes to its organisation (concerns the way ideas and comments are communicated)

6. In the company, communication is very formal, only towards the employee manager, not the other way round. Most of them think that it is insufficient and inconsistent.

7. There is no employee appraisal system in the company which would contribute to the introduction of an incentive system and enable the best employees of retail outlets to increase salaries.

8. There is a high awareness of professionalism among employees, but due to the lack of a motivational system it does not release additional energy for new duties.

It can be concluded that the average employee - a salesman - does not know the organisational culture in his company is and what it is. At Techzbyt company, there is too little communication between middle management and employees in terms of providing information that is highly formalized. There is no system to motivate and support employees in their professional development. The main focus of the company's management is on earning the highest possible profit without taking too much care of the employee. Based on the research, it can be concluded that building a high security culture in the company is primarily favoured by the belief that security is a value connected with every objective of the organisation.

The research shows that most managers of retail outlets cannot properly communicate with the staff. In order to better organise work and create a proper security culture it is essential that

- Managers better inform their subordinates about the elementary principles of organisational culture and elements of their own,

- Introduce an employee appraisal system on the basis of which to build an incentive system,

- $\quad$ Prizes should be related to efficiency and not to internship or other considerations not related to merit,

- $\quad$ Managers must recognise that employees have different motivations and talents,

- Managers should cultivate an efficient company culture,

- Introduce a system of two-way communication, not one-way communication,

- Improve the training system to enable employees to make their own comments and reflections,

Enabling employees to develop and advance professionally.

Organisational culture is created by a set of standards, values and beliefs characteristic of a given organisation, to which employees apply and which determine the way of life of individuals and groups in the organisation. Whereas the security culture is an element of organisational culture. It is a product of individual and group values, attitudes, competences and behaviour patterns that determine involvement in activities related to security management in the organisation and affect the style and effectiveness of this management. The researchers 


\section{ENTREPRENEURSHIP AND SUSTAINABILITY ISSUES}

ISSN 2345-0282 (online) http://jssidoi.org/jesi/

2020 Volume 8 Number 2 (December)

http://doi.org/10.9770/jesi.2020.8.2(26)

Make your research more visible, join the Twitter account of ENTREPRENEURSHIP AND SUSTAINABILITY ISSUES: @Entrepr69728810

focused on one company, what is a research limitation. Nevertheless, we believe that further researchers can echo analysis of the case study and, ultimately, a gap of peculiarities of security culture will be filled in.

\section{References}

Bernardi, A. (2019). The capability approach and organizational climate as tools to study occupational health and safety. Insights into Regional Development, 1(2), 155-169. https://doi.org/10.9770/ird.2019.1.2(6)

Bulgurcu, B., Cavusoglu, H., \& Benbasat, I. (2010). Information security policy compliance: an empirical study of rationality-based beliefs and information security awareness. Mis Quarterly, 34(3), 523-548.

http://130.18.86.27/faculty/warkentin/BIS9613papers/MISQ SpecialIssue/BulgurcuCavusogluBenbasat2010 MISQ34 RationalityAwaren ess.pdf

Cieślarczyk, M. Teoretyczne i metodologiczne podstawy badania problemów bezpieczeństwa i obronności państwa (Theoretical and methodological bases for research on the problems of state security and defence), Wyd. Akademia Podlaska, Siedlce 2009 , p. 157.

Cieślarczyk, M. (2010). Fenomenomen bezpieczeństwa i zjawisko kryzysów postrzegane w perspektywie kulturowej (The phenomenon of security and the phenomenon of crises perceived from the cultural perspective), [in:] Jedność i różnorodność, ed. E. Rekłajtis, B.

Wiśniewski, J. Zdanowski, ASPRA-JR, Warsaw p. 96 et seq.

Douglas, C. (2017). Adapting To Organisational Culture. A StagedAdaptation Model, p. 24,

https://uhra.herts.ac.uk/bitstream/handle/2299/20284/14072596\%20\%20Douglas\%20Claire\%20final\%20version\%20of\%20submission.pdf

?sequence $=1$

Filipek, A. (2008). Poziom i charakter kultury bezpieczeństwa młodzieży akademicademickiej (The level and character of safety culture of academic youth), Wyd. Akademia Podlaska, Siedlce, p. 164.

Gierszewski, J., Drabik, K., Pieczywok, A. (2020). Bezpieczeństwo kulturowe w trakcie zmian spotecznych (Cultural security during societal changes), Difin Warszawa p. 23.

Gherardi, S., Niccolini, D. (2000). The organizational learning of safety in communities of practice. Journal of Management Inquiry, 9(1). https://www.academia.edu/17397679/The_Organizational_Learning_of_Safety_in_Communities_of_Practice

Herath, T., \& Rao, H. R. (2009). Protection motivation and deterrence: a framework for security policy compliance in organisations. European Journal of Information Systems, 18(2), 106-125. https://www.tandfonline.com/doi/abs/10.1057/ejis.2009.6

Horbury, C.R., Bottomley, D.M. (1997). Research into health and safety in the paper industry. Health \& Safety Laboratory, IR/RAS/98/2

Knapp, K. J., Marshall, T. E., Rainer, R. K., \& Ford, F. N. (2006). Information security: management's effect on culture and policy.

Information Management \& Computer Security, 14(1), 24-36.

https://www.emerald.com/insight/content/doi/10.1108/09685220610648355/full/html

Koh, K, Ruighaver. A.B, Maynard, S, Ahmad, A. Security governance: its impact on security culture. In: Proceedings of the third Australian information security management conference, Perth, Australia; September 2005.

https://www.researchgate.net/publication/221148273_Security_Governance_Its_Impact_on_Security_Culture

Kroeber, A. L., \& Kluckhohn, C. (1952). Culture: a critical review of concepts and definitions. Papers. Peabody Museum of Archaeology \& Ethnology, Harvard University, 47(1), viii, 223.

Maynard, S, Ruighaver, AB. (2006). What makes a good information security policy: a preliminary framework for evaluating security policy quality. In: Proceedings of the fifth annual security conference, Las Vegas, Nevada USA; 19-20 April 2006.

https://pdfs.semanticscholar.org/1dc9/a825ec985b02d8215b82bc115a34f2ba9cc5.pdf 


\section{ENTREPRENEURSHIP AND SUSTAINABILITY ISSUES}

ISSN 2345-0282 (online) http://jssidoi.org/jesi/

2020 Volume 8 Number 2 (December)

http://doi.org/10.9770/jesi.2020.8.2(26)

Make your research more visible, join the Twitter account of ENTREPRENEURSHIP AND SUSTAINABILITY ISSUES: @Entrepr69728810

Penc, J. (2010). Kultura i etyka w organizacji. Aspekty pragmatyczne i strategiczne (Culture and ethics in the organization. Pragmatic and strategic aspects), Wydawnictwo Wyższej Szkoły Policji w Szczytnie, Szczytno p. 61

Piwowarski, J. (2016). Nauki o bezpieczeństwie. Zagadnienia elementarne (Security Sciences. Elementary issues. Elementary issues), Wyd. Wyższa Szkoła Bezpieczeństwa Publicznego i Indywidualnego APEIRON, Kraków p. 119. http://apeiron-wydawnictwo.pl/wpcontent/uploads/2019/09/piwowarski-nauki-o-bezp-wydanie-2-2017-book.pdf

Polish Standard PN-N-18001 Systemy zarządzania bezpieczeństwem i higiena pracy, July 1999

Shedden, P, Ahmad, A, Ruighaver, A.B. Risk management standards- the perception of ease of use. In: Proceedings of the fifth annual security conference, Las Vegas, Nevada, USA; 19-20 April 2006.

Shedden, P., Smith, W., Ahmad A. (2010) Information Security Risk Assessment: Towards a Business Practice Perspective, Edith Cowan University Research Online http://citeseerx.ist.psu.edu/viewdoc/download?doi=10.1.1.258.5345\&rep=rep1\&type=pdf

Janusz GIERSZEWSKI is a professor at the Pomeranian University in Słupsk, deputy director of the Institute of Security and Management. Author of about a hundred publications on many aspects of security. Research interests: security, social and cultural threats; sustainable development.

ORCID ID: 0000-0002-8420-7900

Andrzej PIECZYWOK is a professor at the University of Kazimierz Wielki in Bydgoszcz, Research interests: security, social and cultural threats; education for security.

ORCID ID: 0000-0002-4531-0630

Copyright (C) 2020 by author(s) and VsI Entrepreneurship and Sustainability Center

This work is licensed under the Creative Commons Attribution International License (CC BY). http://creativecommons.org/licenses/by/4.0/

c) (7) Open Access 